\title{
PERFORMANCE OF GOATS FED DRIED ORANGE AND CITRUS PULPS AS ENERGY SOURCES, 2-IMPACT OF ADDING PAPPERMINT TO RATIONS CONTAINING DRIED ORANGE OR CITRUS PULPS ON MILK PRODUCTION AND COMPOSITION
}

\author{
Sabbah-Allam and Randa R. El-Elaime \\ Department of Animal Production, Faculty of Agriculture, Cairo University, Egypt.
}

(Received 12/1/2021, accepted 9/3/2021)

\section{SUMMARY}

\begin{abstract}
$\mathrm{T}$ The present study was carried out to evaluate the impact of adding a fixed amount of Peppermint 0.5 $\mathrm{gm} / \mathrm{kg} \mathrm{LBW/} \mathrm{day} \mathrm{to} \mathrm{rations} \mathrm{containing} \mathrm{dried} \mathrm{orange(DOP)} \mathrm{or} \mathrm{citrus} \mathrm{pulps(} \mathrm{DCP} \mathrm{)as} \mathrm{energy}$ sources on milk production, some rumen and blood parameters of Zaraibi does ( Twenty animals averaged 4 years old and weighed on average $45 \mathrm{~kg}$ ). The experiment was started at the last 8 weeks of gestation until three months of suckling period. The experimental rations were : R1(control ration ) consists of $50 \%$ hay and $50 \%$ concentrate mixture which contained $30 \%$ yellow corn grain whileR2( positive control ration) consists of the control ration ( R1) + $0.5 \mathrm{gm}$ Peppermint / $\mathrm{kg} \mathrm{LBW} /$ day.However,50 \% of corn grains in the R1was replaced with $50 \%$ of dried orange pulp (DOP) + $0.5 \mathrm{gm}$ Peppermint / kg LBW/ day ( R3) and $50 \%$ of dried citrus pulp (DCP) +0.5 gm Peppermint / kg LBW/ day ( R4). At the end of the experiment the economic efficiency was calculated. The Results could be summarized as follows .Feeding goats on rations contained dried orange or citrus pulps+ $0.5 \mathrm{gm}$ Peppermint / kg LBW/ day increased nutrients digestibility (CF,CP, EE and NFE) and nutritive values (TDN and DCP) compared to control ration. Dried orange or citrus pulp+ $0.5 \mathrm{gm}$ Peppermint / kg LBW/ day decreased plasma total lipids and cholesterol concentrations, while total plasma protein and globulin were significantly $(\mathrm{P}<0.05)$ increased compared to the control group. Also, improved total milk yield and feed efficiency in all supplemented groups. It could be recommended that adding $0.5 \mathrm{gm}$ Peppermint / kg LBW/ day on dried orange or citrus pulps (Oranges, tangerines, lemons) can safely used to replace a part of the energy sources such as corn grain in rations at $50 \%$ in goats ration to reduce the feeding cost and improving the performance of milk production of goats.
\end{abstract}

Keywords: Orange pulp, citrus pulp, Peppermint, milk production, economic efficiency and goats.

\section{INTRODUCTION}

The main problem in animal production in Egypt is relatively between high prices of concentrates and its ingredients. At the identical time, citrus by-products are also playing a serious contribution in solving this problem in Egypt Bakr (2020). Orange by-products are the residue of peel, pulp and seeds of oranges that remain after fresh fruits of Oranges are squeezed into juice. But citrus by-products are that the residue of peel, pulp and seeds that remain after fresh fruits (Oranges, tangerines, lemons) are squeezed into juice. Dried citrus pulp has high energy content and high digestibility in ruminant species, which make it a common ingredient in ruminant diets (Bampidis et al., 2006).

Citrus consists of many active compounds like limonene, Pinene, Citral, myrcen , $\gamma$-Terpinen, $\beta$ phellandrene and $\beta$ - linalool . Citrus pulp contain over 20 times of V-Trepinen, $\beta$ - Pinene, seven times of citral and 3 times of $\beta$ - citral than orange pulp. but ,citrus pulps contain less limonene $83.15 \%$ than orange pulp $94.46 \%$, These active compounds have several health useful properties like anti-oxidant, antiinflammatory and anticancer Sabbah-Allam and Elelaime (2020a), Bora et al ., (2020).

More studies concluded that up to $50 \%$ of dietary corn grain might be replaced by dried orange or citrus pulps (Oranges, tangerines, lemons) in ruminant rations. But, there are more potential constraints for citrus by - products having an unbalanced $\mathrm{Ca}$ : $\mathrm{P}$ ratio that cause milk fever in dairy cows ( Bampidis et al ., 2006)

Lemonene in the lemon seeds and skins could be a triterpenoid present that caused a bitter taste to citrus pulp. Moreover, large quantities of seeds and limonin content may cause a toxic effect (Fuller, 
2004). There are reports of inflammatory reaction due to lectin hypersensitivity reaction that caused death of several cows fed citrus pulp (Tokarnia et al., 2001).

In order to beat these obstacles, it had been necessary to feature some medicinal herbs that have a soothing and lowering role within the high acidity of citrus pulp .Peppermint contains flavonoids, tannins and volatile oils ( menthol, menthone and limonene ). In addition Peppermint is a good source of vitamins ( $\mathrm{A}, \mathrm{E}, \mathrm{C}, \mathrm{B} 6$, and $\mathrm{K}$, folic acid, beta carotene, and riboflavin) and (minerals : $\mathrm{Ca}, \mathrm{Fe}, \mathrm{K}$ and $\mathrm{Mg}$ ) . Fresh mint could be an antioxidant and anti-inflammatory. Moreover, Peppermint incorporates a wide range of uses. For instance, it can be used as relieve digestive symptoms, such as gas, indigestion and bloating. Elelaime (2007) found that Peppermint, at the rate of $0.5 \mathrm{gm} / \mathrm{kg} \mathrm{LBW} /$ day in goat ration improved milk yield, weight gain of kids, digestibility and bacteriological quality of milk and its manufacturing properties. This study was designed to investigate the impact of adding a fixed amount (0.5 gm) of Peppermint / kg LBW/ day on nutritional values of rations containing dried orange or citrus pulps as partial energy source on the performance of goat does and their milk production.

\section{MATERIALS AND METHODS}

\section{Determination of essential oils in dried orange pulp, citrus pulp and peppermint:}

Triplicate samples of (400 gm each) of air dried orange pulp; citrus pulp and Peppermint were separated by water distillation for $5-6 \mathrm{hr}$. according to the method of Guenther (1961). Analysis of the oil was applied using GLC chromatography.

\section{Determination of Vitamin C and vitamin A in dried orange pulp, citrus pulp:}

Vitamin A and Vitamin C were determined using high-pressure liquid chromatography (HPLC) according to Leth and Sondergaro (1983) according to AOAC (2005)

\section{Determination of Minerals in dried orange pulp and citrus pulp:}

Calcium, $\mathrm{Na}, \mathrm{Mg}, \mathrm{K}, \mathrm{Fe}$, and $\mathrm{Se}$ were analyzed by Atomic Absorption Spectrophotometers using standard procedures of the AOAC (2005). Phosphorus was determined using N-4Cmethod that described by (Kraul 1966). However, selenium was analyzed with an auto- analyzer fluorometric method according to Brown and Watkinson (1977).

\section{Feeding Trials:}

\section{A) Experimental animals:}

TwentyZaraibi does at the last 8 weeks of gestation averaged $45 \mathrm{kgin}$ live body weight were divided into 4 similar groups according to their weight, age and parity. Each group was kept during a separate shaded pen. The experimental period lasted nearly five months. Does were kept under routine veterinary supervision throughout the experiment period.

\section{B) Experimental rations:}

Does were fed control ration( R1 ) contained 50\% alfalfa hay and 50\% concentrate feed mixture (CFM), positive control ( R2 ) contained 50\% alfalfa hay and 50\% concentrate feed mixture (CFM) added with $0.5 \mathrm{gm}$ Peppermint / kg LBW/ day. Does in groups R3 were fed $50 \%$ of sundried orange pulp (DOP)added with0.5 gm Peppermint / kg LBW/ day as partial replacement to $50 \%$ yellow corn grains in the ration. While animals in group R4were fed $50 \%$ of sun dried citrus pulp ( DCP)added with0.5 gm Peppermint / kg LBW/ day as partial replacement to50\% yellow corn grains in the ration.

Fresh orange or citrus juice by-products which contained pulps, peels and seeds were collected and shipped for sun drying to produce DOP and DCP .Does in all groups were received their nutrient requirements according to(NRC, 2007) twice daily at8- am and 3 -pm.Water was always available. The chemical analysis of the experimental rations was carried out according to the AOAC (1996) in the laboratories of Animal Nutrition, Animal Production Department, Faculty of Agriculture, Cairo University. Constituents of the experimental feed mixtures were showed in Table (1). 
Table (1): Constituents of the experimental concentrate feed mixtures.

\begin{tabular}{|c|c|c|c|c|}
\hline \multirow{3}{*}{ Feed ingredient } & \multicolumn{3}{|c|}{ Concentrate feed mixture } & \multirow{3}{*}{$\begin{array}{l}\text { CFM4 } \\
+0.5 \text { gm } \\
\text { Peppermint / } \\
\text { kg LBW/ day }\end{array}$} \\
\hline & CFM1 & CFM2 & CFM3 & \\
\hline & & $\begin{array}{l}+0.5 \text { gm } \\
\text { Peppermint / } \\
\text { kg LBW/ day }\end{array}$ & $\begin{array}{l}+0.5 \text { gm } \\
\text { Peppermint / } \\
\text { kg LBW/ day }\end{array}$ & \\
\hline Yellow corn grain & 30 & 30 & 15 & 15 \\
\hline Dried orange pulp & 0 & 0 & 15 & - \\
\hline Dried citrus pulp & 0 & 0 & - & 15 \\
\hline Wheat bran & 30 & 30 & 30 & 30 \\
\hline Un-decorticated cotton seed & 20 & 20 & 20 & 20 \\
\hline Soya bean meal & 15 & 15 & 15 & 15 \\
\hline Common salt & 1 & 1 & 1 & 1 \\
\hline Di-calcium phosphate & 1.5 & 1.5 & 1.5 & 1.5 \\
\hline *Minerals and vitamins mixture & 2.5 & 2.5 & 2.5 & 2.5 \\
\hline Total & 100 & 100 & 100 & 100 \\
\hline \multicolumn{5}{|c|}{ 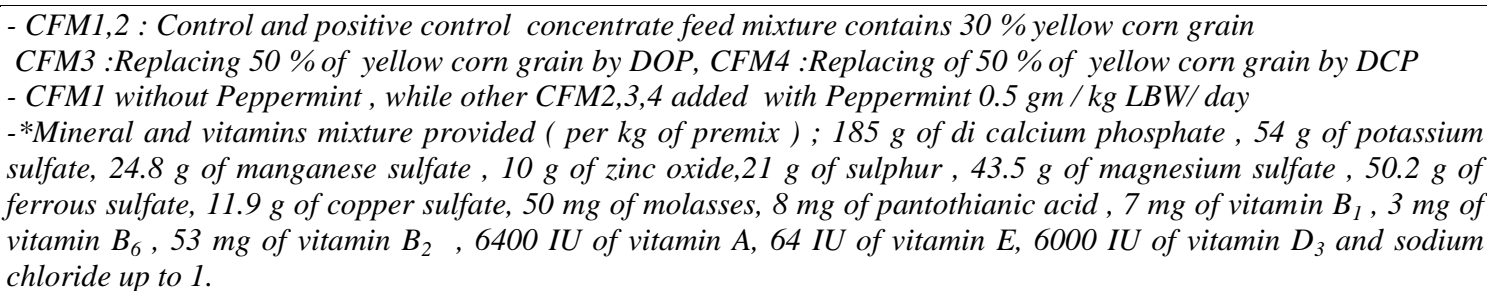 } \\
\hline
\end{tabular}

Chemical analysis of feed ingredients and rations are illustrates in Table (2).

Table (2): Chemical analysis of feed ingredients and the experimental rations (DM basis).

\begin{tabular}{llllllll}
\hline Item & \multicolumn{7}{c}{ Chemical composition \%, on DM basis } \\
\hline & DM & OM & CP & CF & EE & NFE & Ash \\
\hline Alfalfa Hay & 91.0 & 90.0 & 12.5 & 22.0 & 2.6 & 53.4 & 10.0 \\
Dried orange pulp ( DOP) & 90.5 & 92.5 & 6.9 & 12.4 & 4.4 & 68.8 & 7.5 \\
Dried citrus pulp ( DCP) & 86.8 & 92.0 & 6.3 & 12.6 & 3.7 & 69.4 & 8.0 \\
CFM1,2 & 86.8 & 90.0 & 17.9 & 16.0 & 6.6 & 49.5 & 10 \\
CFM 3 with DOP & 86.8 & 92.0 & 17.78 & 18.4 & 6.0 & 49.82 & 8 \\
CFM4 with DCP & 86.8 & 89.6 & 17.82 & 20.5 & 7.0 & 46.28 & 8.4 \\
Ration 1,2 & 88.9 & 90.0 & 15.20 & 19.0 & 4.6 & 51.20 & 10 \\
Ration 3 & 88.9 & 91.0 & 15.14 & 20.2 & 4.7 & 50.96 & 9 \\
Ration 4 & 88.6 & 89.8 & 15.16 & 21.25 & 4.8 & 49.59 & 9.2 \\
\hline
\end{tabular}

\section{Digestibility Trials:}

\section{A) Feeds and feces sampling and analysis}

Twelve mature bucks (weighed $40 \mathrm{~kg}$ ) were randomly selected from the station herd and used in digestion trials ( 3 for each group) for 21 days , 14 days as a preliminary period and 7-days as a collection period. Animals were kept in metabolic cage and fed $90 \%$ of their rations, which provided their maintenance requirements according to NRC (2007). Rations were received twice daily in equal parts at 8.00 and $15.00 \mathrm{hr}$. and water was freely available. During the collection period feces were collected daily and samples representing tenth of the voided feces were taken and then feces samples were dried at $60^{\circ}$ 
$\mathrm{C} / 24 \mathrm{hrs}$ in a hot air oven and analyzed at the end of the collection period according to the methods of the AOAC (1996).

\section{B) Rumen liquor sampling and analysis:}

At the end of the digestibility trials, rumen liquor samples were taken individually using a stomach tube from animals before feeding (zero time), then at 3 and $6 \mathrm{hrs}$. post feeding. Samples were filtered through four layers of surgical gauze, to determine ruminal $\mathrm{pH}$ immediately using digital $\mathrm{pH}$ meter. The samples were kept frozen for testing of various ruminal parameters determination. The microbial protein was measured by sodium tungsten method according to Shultz and Shultz ( 1970 ). Ruminal ammonia N concentration was determined according to Conway (1963), while the total VFA s concentration was determined according to Warner ( 1964)..

\section{Blood sampling and analysis:}

Blood samples were collected biweekly from the jugular vein before feeding at $8-9$ a.m. over the last 2 months of gestation until 3 months of lactation to avoid diurnal variation in the blood chemistry as stated by Thompson and Proctor (1984). The blood samples were centrifuged and then blood plasma was separated into polypropylene tubes and stored until analysis for total proteins and albumin contents according to Doumas et al. (1971), respectively. Globulin value was calculated as the difference between total protein and corresponding value of albumin. . Plasma total lipids (mg/dl) were determined according to Zollner and Kirsch (1962). Plasma cholesterol $(\mathrm{mg} / \mathrm{dl})$ was analyzed according to the method described by Richmond (1973). Plasma (ALT) Alanine Amino Transaminase and Asperate Transaminase (AST) (U/ml) were determined according to Retiman and Frankel (1957)

\section{Milk yield and composition:}

After seven days of parturition the milk yield was individually measured biweekly for each doe once on Tuesday over the 28- weeks period. The does were hand - milked to ensure stripping of the udder. Milk yield was recorded individually. Composite samples were immediately entered for chemical analysis.

Milk samples from does were chemically analyzed to determine fat, protein, total solids and ash percentages. The total solids were determined by drying $10 \mathrm{ml}$ milk sample to constant weight at $100^{\circ} \mathrm{C}$ for $3 \mathrm{hr}$. according to AOAC ( 1996). Ash was determined by evaporating $10 \mathrm{ml}$ milk ( put in crucibles containing ash less filter paper ), dryness and ashing in a muffle furnance at $600^{\circ} \mathrm{C}$ for $2 \mathrm{hr}$.according to AOAC( 1996).

Fat was determined by the classical Gerber method in duplicated with assistance of $90 \% \mathrm{H}_{2} \mathrm{SO}_{4}$ and Amyl alcohol (Ling, 1963). Total nitrogen was determined by micro kildahl procedure AOAC (1996), the factor 6.38 was used to calculate milk protein. Solid not fat ( SNF ) was obtained by difference where , $\mathrm{SNF}=\mathrm{TS}-$ Fat. Cholesterol content was determined calorimetrically according to Pantulu et al ( 1975 ).Fat Corrected Milk ( FCM ) 4\%was calculated $=[(0.4 \times \mathrm{kg}$ milk $)+(0.15 \times \mathrm{kg}$ milk $\times$ fat $\%)]$ according to Gaines (1928). Calcium, P, K, Na, Mg, Fe, and Se were determined in ash according to Jackson (1958) using Atomic absorption spectrophotometer.

\section{Economic efficiency:}

The economic efficiency values were calculated as:

-Out put $=$ price of total milk consumed during suckling period

-Input $=$ total feed cost $/$ goat .

- Net revenue $=$ output - input .

- Economic efficiency $=($ Net revenue $) /($ Total feed cost $)$

Different prices of the experimental diets were calculated according to the current prices of the ingredients for different experimental rations .

\section{Statistics analysis:}

The obtained data were analyzed using the general linear model procedure of SAS (2001), as the following model: 


$$
Y i j=\mu+T i+E i j
$$

Where:

Yij $=$ Observed value of a given dependent variable.

$$
\begin{aligned}
\mu & =\text { General mean. } \\
\mathrm{Ti} & =\text { The effect of treatments. } \\
\text { Eij } & =\text { The experimental random error. }
\end{aligned}
$$

Significant differences among means were separated by Duncan's multiple range test (Duncan, 1955)

\section{RESULTS AND DISCUSSION}

\section{Essential oils contents of peppermint:}

The analysis of the essential oils of peppermint in Table (3)indicated that Peppermint contains numerous active metabolites such as linalool, myrcene, menthol, menthone and thymol. These results are in harmony with Sabbah-Allam and Elelaime (2020b) who reported that Peppermint is used in animal nutrition because they rich in thymol, menthol and many compounds which have a wide range of properties such as antimicrobial, immune-stimulant and anti-oxidative activities, and the ability to enhance intestinal absorption, to improve growth and even to reduce cumulative mortality.

In contrast, Peppermint contains flavonoids, primarily of menthol (29-48\%), menthone (20-31\%), menthofuran $(6.8 \%)$ and menthyl acetate $(3-10 \%)$. Other medical active ingredients include bitter substances such as flavonoids (12\%), polyphenols (19\%), carotenes, tocopherols, betaine, choline and tannins (Elelaime, 2007).

Table (3): The constituents of essential oils in Peppermint.

\begin{tabular}{llc}
\hline No. & Components & Content $(\%)$ \\
\hline 1 & Thymoquinone & 42.92 \\
2 & P- cymene & 21.61 \\
3 & D-Limonene & 8.71 \\
4 & Nerol & 1.52 \\
5 & Borneol & 2.14 \\
6 & Phellendrene & 3.90 \\
7 & Linalool & 5.19 \\
8 & $\gamma$-Terpinen & 3.23 \\
9 & $\alpha-$ pinene & 1.98 \\
10 & Cineole & 1.64 \\
11 & Eugenol & 2.28 \\
12 & Myrecene & 1.37 \\
13 & B-Pinene & 2.53 \\
14 & Thymol & 0.980 \\
\hline
\end{tabular}

\section{Vitamins content:}

Data in Table (4) cleared that DOP contained $12.63 \mathrm{mg} / 100 \mathrm{~g}$ of vitamin C and $32.41 \mathrm{IU}$ of vitamin A, However the DCP contained $11.68 \mathrm{mg} / 100 \mathrm{~g}$ of vitamin C and $43 \mathrm{IU}$ of vitamin A.

Table (4): Vitamins content of dried orange and citrus by-products.

\begin{tabular}{lll}
\hline Vitamins content & Orange pulp & Citrus pulp \\
\hline Vitamin C & $12.63 \mathrm{mg} / 100 \mathrm{~g}$ & $11.68 \mathrm{mg} / 100 \mathrm{~g}$ \\
Vitamin A & $32.41 \mathrm{IU}$ & $43 \mathrm{IU}$ \\
\hline
\end{tabular}

\section{Minerals of the tested DOP and DCP:}

The DOP contained 20, 1.84, 3.4 and $0.26 \mathrm{mg} / 100 \mathrm{~g}$ of $\mathrm{Ca}, \mathrm{P}, \mathrm{Mg}$ and $\mathrm{Na}$, respectively. Also, it contains $0.060,0.082$ and $0.030 \mathrm{mg} / 100 \mathrm{~g} \mathrm{DM}$ of Fe, Se and $\mathrm{Zn}$, respectively. Moreover, The DCP 
contained 14, 1.67, 0.41 and $2.9 \mathrm{mg} / 100 \mathrm{~g}$ of $\mathrm{Ca}, \mathrm{P}, \mathrm{Na}$, and $\mathrm{Mg}$, respectively. Also, it contains 0.048 , 0.090 and $0.05 \mathrm{mg} / 100 \mathrm{~g} \mathrm{DM}$ of Fe, Se and Zn, respectively (Table 5).

Table (5): Minerals content of dried orange and citrus by-products.

\begin{tabular}{lcc}
\hline Minerals & Orange pulp & Citrus pulp \\
\hline Macro-elements $(\mathrm{mg} / 100 \mathrm{~g})$ & 20 & 14 \\
$\mathrm{Ca}$ & 1.84 & 1.67 \\
$\mathrm{P}$ & 3.4 & 2.9 \\
$\mathrm{Mg}$ & 0.26 & 0.41 \\
$\mathrm{Na}$ & & \\
$\mathrm{Micro}-$ elements & 0.060 & 0.048 \\
$\mathrm{Fe}$ & 0.082 & 0.090 \\
$\mathrm{Se}$ & 0.03 & 0.05 \\
$\mathrm{Zn}$
\end{tabular}

\section{Nutrients digestibility and nutritive value of experimental rations:}

Results in Table (6)demonstrated that using dried citrus or orange pulps increased all nutrients digestibility and nutritive value as TDN compared to the control ration by 73.27- 75.72 for CP , 64.1067.30for CF and69.00-71.21for NFE. Also, Results showed higher significant values of TDN in the tested rations than the control group. In the same time rations contains peppermint (R2, R3 and R4) tended to have significantly ( $\mathrm{p}<0.05$ ) higher nutritive value as DCP compared with control group. Moreover, results showed that adding peppermint to the control ration increased all nutrients digestibility. The differences for CF, TDN and DCP were significant. These results are in harmony with those observed by Elelaime (2007) and Sabbah-Allam and Elelaime (2020b) that the addition of Peppermint at level $0.5 \mathrm{gm} / \mathrm{kg} \mathrm{LBW} /$ day improved organic matter, crude protein, crude fiber, nitrogen free extract digestibility and nutritive value as TDN, Allam et al. (2011) found that the improvement of CF digestibility might be due to the fact that dried orange pulp (DOP) contains a high concentration of pectin leading to a fast degradation in rumen and releasing energy for a rapid microbial growth which produces lesser lactate than starch.

Table (6 ): Nutrients digestibility and nutritive value ( \% DM basis) of the experiment rations.

\begin{tabular}{|c|c|c|c|c|c|}
\hline \multirow[t]{2}{*}{ Item } & \multicolumn{5}{|c|}{ Experimental ration } \\
\hline & $\mathrm{R} 1$ & $\mathrm{R} 2$ & R3 & $\mathrm{R} 4$ & $\underline{ \pm S E M}$ \\
\hline \multicolumn{6}{|c|}{ Nutrients digestibility $\%$} \\
\hline DM & $58.13^{\mathrm{b}}$ & $62.78^{\mathrm{a}}$ & $63.37^{\mathrm{a}}$ & $64.15^{\mathrm{a}}$ & 0.948 \\
\hline $\mathrm{OM}$ & $60.20^{c}$ & $63.60^{\mathrm{b}}$ & $64.30^{\mathrm{ab}}$ & $64.57^{\mathrm{a}}$ & 0.790 \\
\hline $\mathrm{CP}$ & $69.00^{c}$ & $73.27^{\mathrm{b}}$ & $75.59^{\mathrm{a}}$ & $75.72^{a}$ & 0.875 \\
\hline $\mathrm{EE}$ & $72.79^{c}$ & $74.90^{\mathrm{b}}$ & $75.82^{\mathrm{a}}$ & $75.66^{\mathrm{a}}$ & 0.861 \\
\hline $\mathrm{CF}$ & $61.48^{\mathrm{c}}$ & $64.10^{\mathrm{b}}$ & $68.07^{\mathrm{a}}$ & $67.30^{\mathrm{a}}$ & 0.890 \\
\hline NFE & $64.67^{\mathrm{c}}$ & $69.00^{\mathrm{b}}$ & $69.99^{\mathrm{b}}$ & $71.21^{\mathrm{a}}$ & 0.683 \\
\hline \multicolumn{6}{|c|}{ Nutritive values (\%) } \\
\hline TDN & $62.8^{\mathrm{c}}$ & $66.39^{\mathrm{b}}$ & $68.52^{\mathrm{a}}$ & $69.24^{\mathrm{a}}$ & 0.970 \\
\hline DCP & $10.49^{\mathrm{c}}$ & $11.14^{\mathrm{b}}$ & $11.09^{\mathrm{b}}$ & $11.46^{\mathrm{a}}$ & 0.140 \\
\hline
\end{tabular}

$a, b, c:$ means on the same row with different superscript are significantly different $(P<0.05)$.

\section{Rumen liquor parameters:}

Results in Table (7) showed that the mean differences of ruminal $\mathrm{pH}$ values and ammonia-N concentrations among treatments were not significant. The ruminal $\mathrm{NH}_{3}-\mathrm{N}$ concentration increased at 3 hrs post feeding, but it decreased at $6 \mathrm{hrs}$ post feeding for all treatments. 
Using dried orange or citrus pulps improved the volatile fatty acids concentrations (meq/ $100 \mathrm{ml}$ ) which indicate that dried orange or citrus pulps are better energy source than corn grain for rumen microorganisms, promoting a higher concentration of total volatile fatty acids. Also, results indicate that adding peppermint to the control ration showed higher total VFAS (meq/100 ml) than the negative control. These results are in harmony with those observed by Sabah-Allam and Elelaime (2020b) who reported that the addition of Peppermint at level $0.5 \mathrm{gm} / \mathrm{kg} \mathrm{LBW} /$ day increased $(\mathrm{p}<0.05$ )the volatile fatty acids concentrations (meq/100 ml)of rumen fluid than the control group. Increasing the volatile fatty acids concentration of the experimental rations compared with control group may be due to the increase in OM digestibility in the experimental groups.

Data showed a significant decrease $(\mathrm{P}<0.05)$ of overall means value of microbial protein compared with control group. The lowest value was for R4 followed byR3and R2 (positive control), which was significantly less than the control and significantly higher than R3 and R4. Decreasing of microbial protein of groups fed R4, R3 and R2 may be due to the adverse ( an antimicrobial ) effect of Peppermint, orange and citrus pulps on microbial protein synthesis in the rumen .

However results indicate that adding Peppermint improved dried citrus or orange pulps as partial corn replacement in ruminant rations.

Table (7): Effect of experimental rations on rumen liquor parameters.

\begin{tabular}{|c|c|c|c|c|c|c|}
\hline \multirow[t]{2}{*}{ Item } & \multicolumn{6}{|c|}{ Experimental ration } \\
\hline & Time & $\mathrm{R} 1$ & $\mathrm{R} 2$ & R3 & $\mathrm{R} 4$ & SEM \\
\hline \multirow[t]{4}{*}{$\mathrm{pH}$ value } & 0 & 6.50 & 6.60 & 6.70 & 6.70 & - \\
\hline & 3 & 6.00 & 6.00 & 6.25 & 6.30 & - \\
\hline & 6 & 6.30 & 6.40 & 6.55 & 5.60 & - \\
\hline & Mean & 6.27 & 6.33 & 6.50 & 6.20 & 0.084 \\
\hline Ammonia - N & 0 & 27.00 & 23.60 & 22.80 & 24.30 & - \\
\hline \multirow[t]{3}{*}{$(\mathrm{mg} / 100 \mathrm{ml})$} & 3 & 34.20 & 33.90 & 34.20 & 34.50 & - \\
\hline & 6 & 30.00 & 30.70 & 31.80 & 31.60 & - \\
\hline & Mean & 30.4 & 29.4 & 29.60 & 30.13 & 0.870 \\
\hline Total VFAs & 0 & 9.30 & 9.60 & 10.20 & 10.40 & - \\
\hline \multirow[t]{4}{*}{ (meq/100ml) } & 3 & 10.20 & 10.50 & 10.80 & 11.20 & - \\
\hline & 6 & 9.60 & 9.70 & 9.80 & 10.00 & - \\
\hline & Mean & $9.7^{\mathrm{c}}$ & $9.93^{\mathrm{b}}$ & $10.27^{\mathrm{a}}$ & $10.53^{\mathrm{a}}$ & 0.520 \\
\hline & 0 & $255^{\mathrm{a}}$ & $250^{\mathrm{a}}$ & $242^{\mathrm{b}}$ & $240^{\mathrm{b}}$ & 4.100 \\
\hline \multirow{2}{*}{$\begin{array}{l}\text { Microbial } \\
\text { protein }\end{array}$} & 3 & $290^{\mathrm{a}}$ & $280^{\mathrm{b}}$ & $272^{\mathrm{c}}$ & $266^{\mathrm{c}}$ & 4.630 \\
\hline & 6 & $270^{\mathrm{a}}$ & $260^{\mathrm{b}}$ & $250^{\mathrm{c}}$ & $245^{\mathrm{c}}$ & 4.970 \\
\hline ( mg/ 100 ml ) & Mean & $271.7^{\mathrm{a}}$ & $263.3^{\mathrm{b}}$ & $254.7^{\mathrm{c}}$ & $250.3^{\mathrm{c}}$ & 5.020 \\
\hline
\end{tabular}

a,b,c: means on the same row with different superscript are significantly different $(P<0.05)$.

\section{Blood parameters:}

Data in Table (8) showed no significant differences for ALT and AST enzymes. But using dried citrus or orange pulps and adding Peppermint at the rate of $0.5 \mathrm{gm} / \mathrm{kg} \mathrm{LBW} /$ day decreased cholesterol levels with a high effect $134 \mathrm{mg}$ / dl for R4followed by R3 and R2, comparing with the control group. These results are in harmony with those observed by Al- Qudah (2018) that eating Lemon peel can reduce cholesterol level effectively, this is not related to lemon peel pectin level, but because of various active ingredients in the peel. 
Moreover, dried citrus or orange pulps decreased total lipid and increased total protein and albumin with significant difference $(\mathrm{P}<0.05)$ comparing with the control group. Also, globulin level showed a higher significant difference $(\mathrm{P}<0.05)$ for $\mathrm{R} 4$ followed byR3 and R2 than R1.

Increasing the globulin level with citrus or orange pulps with peppermint addition may be due to their component from steroidal flavonoids which stimulate the normal secretion of cortisone, meanwhile seventy percent from this cortisone bind with globulin El-Elaime (2007). These results are in harmony with those observed by Sabbah-Allam and Elelaime (2020b) who reported that the addition of Peppermint at level $0.5 \mathrm{gm} / \mathrm{kg} \mathrm{LBW} /$ day increased ( $<0.05$ ) the total protein, albumin, globulin and decreased total lipids and cholesterol than the control group.

Table (8): Mean values of blood constituents recorded for experimental groups.

\begin{tabular}{lccccc}
\hline Item & \multicolumn{5}{c}{ Experimental ration } \\
\cline { 2 - 6 } & R1 & R2 & R3 & R4 & $\underline{ \pm}$ SEM \\
\hline Total protein & $7.4^{\mathrm{c}}$ & $7.9^{\mathrm{b}}$ & $8.2^{\mathrm{a}}$ & $8.3^{\mathrm{a}}$ & 0.180 \\
Albumin & $3.6^{\mathrm{b}}$ & $3.7^{\mathrm{b}}$ & $3.9^{\mathrm{a}}$ & $3.9^{\mathrm{a}}$ & 0.123 \\
Globulin & $3.8^{\mathrm{c}}$ & $4.2^{\mathrm{b}}$ & $4.3^{\mathrm{b}}$ & $4.4^{\mathrm{b}}$ & 0.120 \\
Total lipid & $376^{\mathrm{a}}$ & $368^{\mathrm{b}}$ & $366^{\mathrm{b}}$ & $360^{\mathrm{c}}$ & 5.98 \\
Cholesterol & $160^{\mathrm{a}}$ & $145^{\mathrm{b}}$ & $140^{\mathrm{b}}$ & $134^{\mathrm{c}}$ & 3.95 \\
ALT & 18.0 & 18.1 & 18.0 & 18.0 & 0.117 \\
AST & 37.9 & 37.8 & 37.7 & 38.0 & 0.230 \\
\hline
\end{tabular}

$a, b, c:$ means on the same row with different superscript are significantly different $(P<0.05)$.

\section{Milk composition:}

Data in Table (9) showed no significant differences detected for TS, SNF, CP, lactose and ash content. Using dried citrus or orange pulps decreased $(\mathrm{p}<0.05)$ the cholesterol content of goat's milk compared to the control group. The level was $20 \mathrm{mg} / 100 \mathrm{ml}$ for R4 followed by R3 and R2, compared to the control group, while fat content increased significantly compared to the control group.

Generally, the addition of Peppermint at level $0.5 \mathrm{gm} / \mathrm{kg} \mathrm{LBW} /$ day decreased $(\mathrm{P}<0.05)$ the cholesterol content of goats milk comparing with the control group. These results are in harmony with Elelaime (2007) and Sabbah-Allam and Elelaime $(2020 \mathrm{~b})$ that the addition of Peppermint at level $0.5 \mathrm{gm}$ / $\mathrm{kg} \mathrm{LBW} /$ day decreased $(\mathrm{P}<0.05$ ) the cholesterol content of goats milk comparing with the control group.

Also, data showed significant improvement of calcium and iron contents in milk .This improvement might be due to the fact that DCP, DOP and peppermint are rich in iron and calcium as mentioned by Czech et al. (2020) that both of pulp and peel of citrus fruits are valuable sources of macro- and micronutrients. Lemon is rich in calcium, sodium, zinc and especially potassium . While, orange is rich in iron and copper

Table (9): Effect of the experimental rations on milk composition.

\begin{tabular}{llllll}
\hline Milk composition \% & \multicolumn{5}{l}{ Experimental rations } \\
\cline { 2 - 6 } & R1 & R2 & R3 & R4 & +SEM \\
\hline TS & 12 & 12.28 & 12.32 & 12.40 & 0.085 \\
Fat & $3.20^{\mathrm{b}}$ & $3.58^{\mathrm{a}}$ & $3.64^{\mathrm{a}}$ & $3.70^{\mathrm{a}}$ & 0.120 \\
SNF & 8.80 & 8.70 & 8.68 & 8.70 & 0.032 \\
CP & 3.40 & 3.42 & 3.44 & 3.50 & 0.006 \\
Lactose & 4.50 & 4.60 & 4.60 & 4.60 & 0.001 \\
Ash & 0.80 & 0.80 & 0.82 & 0.83 & 0.002 \\
Cholesterol $(\mathrm{mg} / 100 \mathrm{ml})$ & $29^{\mathrm{a}}$ & $25^{\mathrm{b}}$ & $24^{\mathrm{b}}$ & $20^{\mathrm{c}}$ & 0.971 \\
Ca $(\mathrm{gm} / 1000 \mathrm{ml})$ & $1.20^{\mathrm{b}}$ & $1.30^{\mathrm{ab}}$ & $1.52^{\mathrm{a}}$ & $1.66^{\mathrm{a}}$ & 0.230 \\
Fe $(\mathrm{mg} / 1000 \mathrm{ml})$ & $0.52^{\mathrm{b}}$ & $0.70^{\mathrm{a}}$ & $0.76^{\mathrm{a}}$ & $0.78^{\mathrm{a}}$ & 0.140 \\
\hline
\end{tabular}

$a, b, c:$ means on the same row with different superscript are significantly different $(P<0.05)$.

\section{Milk yield}

Results of mean value of milk yield Table (10) showed that using dried citrus or orange pulps with Peppermint showed better milk production compared to the control ration. The mean value of total milk 
yield during 12 weeks of lactation period was $114.1,126.14,133$ and 134.82 for R1, R2, R3 and R4 respectively (Table 10).

Using dried citrus or orange pulps and adding Peppermint increased total milk yield and Fat Corrected Milk (FCM) 4\% compared with control group. The effect was the highest for R4 followed by R3 and R2 compared with control group. These results are in harmony with those of Allam et al.(2020) who found an improvement in milk yield of Holstein cows fed rations containing DOP.

Table (10): Effect of the experimental rations on milk yield and feed efficiency of does during suckling period.

\begin{tabular}{|c|c|c|c|c|c|}
\hline \multirow[t]{2}{*}{ Item } & \multicolumn{5}{|c|}{ Experimental ration } \\
\hline & R1 & R2 & R3 & $\mathrm{R} 4$ & \pm SEM \\
\hline \multicolumn{6}{|l|}{ Total milk production , $\mathrm{kg} /$ doe } \\
\hline Milk yield & $114.1^{\mathrm{c}}$ & $126.14^{\mathrm{b}}$ & $133^{\mathrm{a}}$ & $134.82^{\mathrm{a}}$ & 1.203 \\
\hline Fat $\%$ & $3.20^{\mathrm{b}}$ & $3.58^{\mathrm{a}}$ & $3.64^{\mathrm{a}}$ & $3.70^{\mathrm{a}}$ & 0.120 \\
\hline $\mathrm{FCM}^{*} 4 \%$ fat & $100.41^{\mathrm{c}}$ & $118.19^{\mathrm{b}}$ & $125.82^{\mathrm{a}}$ & $128.75^{\mathrm{a}}$ & 1.263 \\
\hline Total fat produce, $\mathrm{kg} / \mathrm{doe}$ & $3.65^{\mathrm{c}}$ & $4.52^{\mathrm{b}}$ & $4.84^{\mathrm{ab}}$ & $4.99^{\mathrm{a}}$ & 0.207 \\
\hline $\mathrm{CP} \%$ & 3.40 & 3.42 & 3.44 & 3.50 & - \\
\hline Total protein produced $\mathrm{kg} /$ doe & $3.88^{\mathrm{c}}$ & $4.29^{\mathrm{b}}$ & $4.58^{\mathrm{ab}}$ & $4.72^{\mathrm{a}}$ & 0.384 \\
\hline \multicolumn{6}{|l|}{ Total feed intake , kg / doe } \\
\hline As DM kg & 120 & 123 & 126 & 127 & - \\
\hline As TDN $\mathrm{kg}$ & 75.36 & 81.66 & 86.34 & 87.94 & - \\
\hline As DCP kg & 12.59 & 13.70 & 13.97 & 14.55 & - \\
\hline \multicolumn{6}{|l|}{ Feed efficiency } \\
\hline kg milk / kg DM & 0.950 & 1.026 & 1.056 & 1.062 & - \\
\hline Price / kg feed (L.E.) & 4.05 & 4.06 & 3.67 & 3.67 & - \\
\hline Total feed cost / goat (L.E.) & 486 & 499.38 & 462.42 & 466.09 & - \\
\hline Feed cost / kg milk (L.E.) & 4.26 & 3.96 & 3.48 & 3.46 & - \\
\hline Feed cost / kg FCM (L. E. ) & 4.84 & 4.23 & 3.68 & 3.62 & - \\
\hline
\end{tabular}

$a, b, c:$ means on the same row with different superscript are significantly different $(P<0.05)$

\section{Economic evaluation:}

Data of economic evaluation of lactating goats production are summarized in Table (11).Using dried citrus or orange pulps with Peppermint improved economic efficiency and relative economic efficiency of dams. The effect was the highest for R4 followed by R3 comparing with R1 and R2 groups.

Table (11): Economic evaluation of the experimental rations.

\begin{tabular}{lccccc}
\hline Item & \multicolumn{5}{c}{ Experimental rations } \\
\cline { 2 - 6 } & $\mathrm{R} 1$ & $\mathrm{R} 2$ & $\mathrm{R} 3$ & $\mathrm{R} 4$ & +SEM \\
\hline Total feed intake ( as DM), kg/ doe during suckling & 120 & 123 & 126 & 127 & - \\
period (3 months ) & & & & & - \\
Total feed cost / goat (L.E.) & 486 & 499.38 & 462.42 & 466.09 & - \\
Average of total milk yield during suckling period. & 114.1 & 126.14 & 133 & 134.82 & - \\
Price of total milk consumed & 1140 & 1261.4 & 1330 & 1348.2 & - \\
Net revenue & 654 & 762.02 & 867.58 & 882.11 & 0.127 \\
Economic efficiency ( LE ) & $1.35^{\mathrm{c}}$ & $1.53^{\mathrm{b}}$ & $1.88^{\mathrm{a}}$ & $1.89^{\mathrm{a}}$ & - \\
Relative Economic efficiency & 100 & 113.33 & 139.3 & 140 & - \\
\hline
\end{tabular}

Market prices were as follow: Total concentrate mixture were 4500LE/Ton, alfalfa hay was 3000LE/Ton, peppermint $5 \mathrm{LE} / \mathrm{kg}, \mathrm{DOP}$ and DPP were $750 \mathrm{LE}$.

Economic efficiency $=($ Net revenue $) /($ Total feed cost $)$ 


\section{CONCLOSIONS}

Referring to the obtained results, it is recommended that: adding Peppermint at $0.5 \mathrm{gm} / \mathrm{kg} \mathrm{LBW} / \mathrm{day}$ to the lactating goats rations containing dried orange or citrus pulps as energy sources could improve milk yield, feed efficiency and economic efficiency .

\section{REFERENCES}

Allam, Sabbah A.; Abou- ward,G.A.; Ali, M.A.; Al-Hossieny , H.M. and S.I. El-Naggar (2011). Nutritional and economical impact of using dried orange pulp as energy source in growing lambs ration, Egyptian J. Nutrition and Feeds. 14 (3): 337- 347.

Allam, Sabbah A. and R.R. Elelaime (2020a). Performance of goats fed dried orange and citrus pulps as energy source. 1- Impact of feeding orange or citrus pulps on milk production and composition. Egyptian Journal of Nutrition and Feeds. 23 (3): 349-358.

Allam, Sabbah.A. and R.R. Elelaime (2020b). Impact of garlic, lemongrass, peppermint and rosemary as feed additives on performance of growing Barki lambs . Egyptian Journal of Nutrition and Feeds. 23 (3): $359-367$

Al-Qudah,T.S.;Rehman , R.;Majeed, M.I. ;Nisar S. and R.W. Tahtamoni (2018). Lemon as a source of functional and medicinal ingredient: A review .International Journal of Chemical and Biochemical Sciences 14: $55-61$

AOAC (1996). Association of Official Analytical Chemists, Official Methods of Analysis, $13^{\text {th }}$ Ed. Washington, D. C, USA.

AOAC (2005). Association of Officiating Analytical Chemists. Official Method of Analysis. $18^{\text {th }}$ Edition, Washington DC, Method 935.14 and 992.24.

Bakr, M. H.(2020). Citrus pulp as an innovative feed ingredient in ruminant nutrition . A review. Egyptian J.Anim. Prod., 57: 73-80.

Bora, H. ; Kamle,M. ; Mahato,D.K. ;Tiwari, P. and P. Kumar (2020).Citrus essential oils and their applications in food. Plants, 9: 357-382.

Brown M.W. and J.H. Watkinson (1977). An automated fluorometric method for the determination of nano-gram quantities of selenium. Anal. Chem. Acta, 89:29-35

Czech, A. ; Zaryacka, E.; Yanovych,D.; Grzegorczyk and S.Klys (2020). Mineral content of pulp and peelof various citrus fruit cultivars. Biological Trace Element Research, 193 (68):555- 563

Conway, E.F. (1963). Modification analysis and volumetric error. Rev. Ed. Look Wood, London.

Doumas , B.; W. Wabson and H. Biggs (1971). Albumin standard and measurement of serum with bromocresol green. Clin. Chem. Acta, 32:81.

Duncan, D. B. (1955). Multiple tests. Biometrics 11: 1 - 42.

Elelaime,R.R. (2007).Performance of goats feed certain medicinal herbs with reference to milk production and its manufacture. PhD. Faculty of Agric, Cairo University, Egypt.

Gaines, W.L. (1923). Relation between percentage of fat content and yield of milk . 1 - correction of milk yield for fat content. Agric. Handbook 379, USDA Washington, DC, USA.

Guenther, D. (1961). The essential oils. Van No Strand Company, $4^{\text {th }}$ ed.New York, London .

Jackson , M.L. (1958). Soil chemical analysis. Verlag: Prentice Hall,Inc., Englewood Cliffs , N.J.498

Kraul, M. (1966). Semi-automated determination of phosphor-lipid. Clin Chem Acta 13:442-446

Leth T. andH .Sondergaro (1983). Biological activity of all-trance tocopheroldetermined by three different rat bioassays. Int J Vit Nutr Res 53:297-311

Ling, E.R. (1963). Atext book of dairy chemistry. Vol. 2, Chapman and Hall Ltd, London.

NRC (2007). National Research Council. Nutrient Requirements of Small Ruminants Sheep, Goats, and world Camels. National Academies Press, Washington, DC., USA. 
Pantlulu P.C.;M.D., Bhimasenara andC.P. Anantakrishnan (1975). Application of Lieberman-Bur-Chard reaction to the unsaponifiable portion of milk lipids as a criterion for the quantitive determination of cholesterol in milk and milk products. Milch Nissenschaft 30 (12) 195 - 210.

Retiman , A. and S. Frankel ( 1957). A colorimetric method for the determination of plasma glutamic oxaloacetic and glutamic pyruvic transaminase. Amer J. Clin. Path., 28:56 - 63.

Richmond, W. (1973). Determination of plasma cholesterol . Clin. Chem., 19: 1350.

SAS ( 2001) : “SAS Users Guide : Statistics . Version 5 Edition. SAS Inc., Carry, NC.

Sabbah-Allam.; T.M. El-Bedawy ; M.H.Bakr and A.E. Mahmoud (2020). Effect of feeding dried orange pulp to lactating dairy cows on nutrients digestibility, blood constituents, plasma antioxidant biomarker and pathogenic fecal bacteria. Pakistan J, Zool., 52 (1): 79-68

Shultz, T.A.and E. Shultz (1970). Estimation of rumen microbial nitrogen by three analytical methods. J. Dairy science, 53: 781-784.

Thompson, R.B. and S.J. Proctor (1984). A short text book of hematology $6^{\text {th }}$ ed. English language, Book Society, pitman.

Tokarnia, C. H. ; Peixoto, P. V. and B. R. Cunha (2001). Experiments with citrus pulp in sheep and rabbits. Pesq. Vet. Bras., 21 (4): 172-176

Warner, A.C.I. (1964). Production of volatile fatty acids in the rumen methods of measurement. Nutr. Abst. Rev., 34: 339.

Zollner sN. and K. Kirsch (1962). Determination of Total Lipids. Journal of Experimental Medicine 135: 545- 550. 


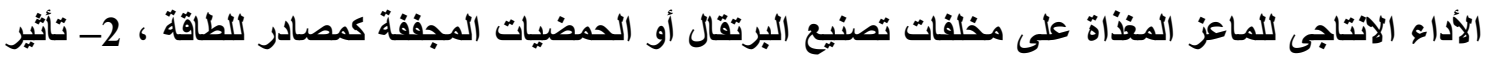 اضافة النعناع على العلائق المحتوية على مخلفات تصنيع البرتقال أو الحمضيات المجففة على إنتاج اللبن و التواتئ

\author{
صباح محمود علام و رندا رفاعى السيد العليمى \\ قسم الانتاج الحيوانى- كلية الزراعة - جامعة القاهرة- مصر.
}

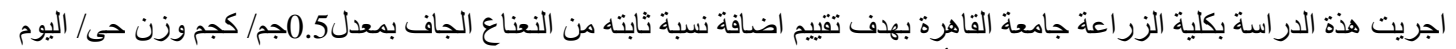

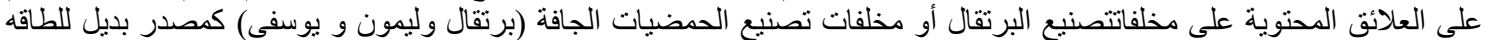

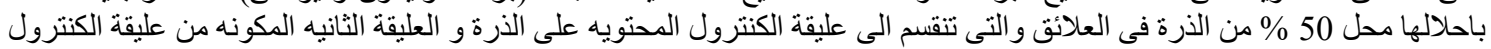

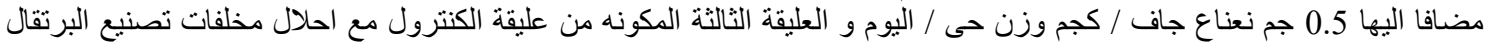

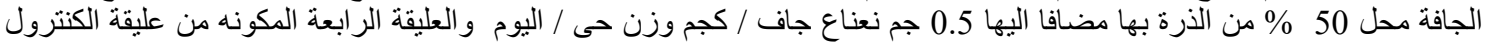

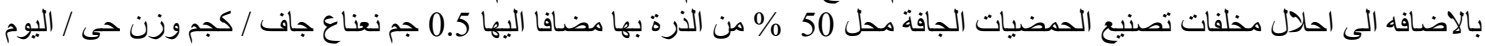

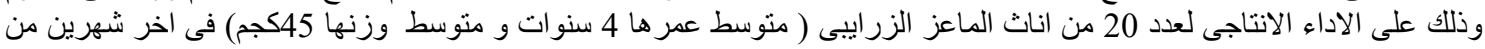

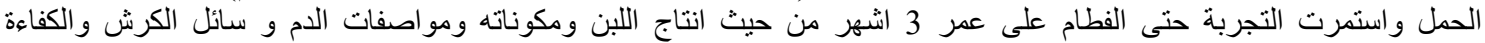
الاقتصادية ولقد اظهرت النتائج ما يلى:

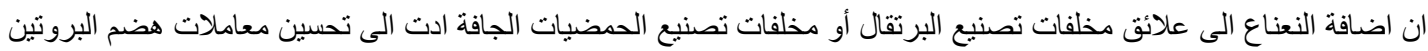

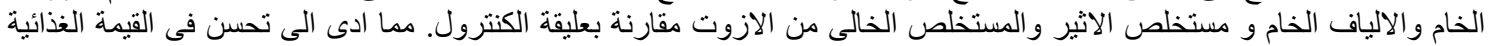

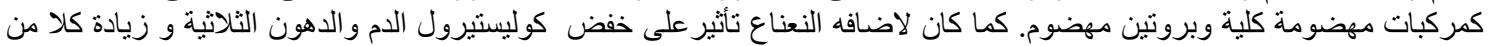

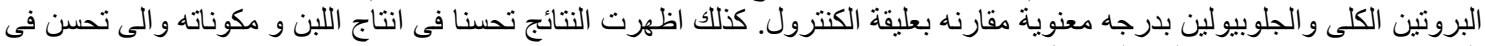
الكفاءة الاقتصادية مقارنة بعليقة الكنترول.

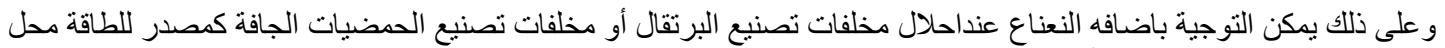

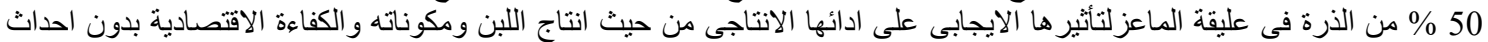
تأثير ات سلبية على صحة الحيوان. 